\title{
PENGURANGAN FFA DAN WARNA DARI MINYAK JELANTAH DENGAN ADSORBEN SERABUT KELAPA DAN JERAMI
}

\author{
Julius Fernando Pakpahan, Tomas Tambunan, Agnes Harimby, M. Yusuf Ritonga \\ Departemen Teknik Kimia, Fakultas Teknik, Universitas Sumatera Utara, \\ Jalan Almamater Kampus USU Medan 20155, Indonesia \\ E-mail: juli_us13@yahoo.com
}

\begin{abstract}
Abstrak
Minyak jelantah adalah minyak goreng yang sudah digunakan beberapa kali pemakaian. Selain warnanya yang tidak menarik dan berbau tengik, minyak jelantah juga mempunyai potensi besar dalam membahayakan kesehatan tubuh. Minyak jelantah dapat dimanfaatkan kembali dengan cara mengadsorpsi kotoran-kotoran dan warna yang terdapat di dalam minyak jelantah dengan menggunakan adsorben. Penelitian ini bertujuan untuk mengurangi kadar FFA dan warna dari minyak jelantah dengan menggunakan adsorben serabut kelapa dan jerami dengan variasi ukuran 50,70 dan 100 mesh, tekanan dibawah 1 atm dan 1 atm, serta waktu adsorpsi setiap 10 menit selama $1^{1} \frac{1}{2}$ jam. Dalam penelitian ini adsorben yang paling baik digunakan pada penurunan bilangan asam (FFA) adalah serabut kelapa dengan tekanan dibawah 1 atm dimana bilangan asam sebelum diadsorpsi sebesar 0,006823 $N$ dan setelah diadsorpsi menjadi $0,0002924 \mathrm{~N}$, sedangkan untuk pengurangan warna, adsorben jerami padi dengan ukuran 100 mesh lebih efektif karena mengurangi warna dari 5,5 red dan 24 yellow menjadi 3,3 red dan 21 yellow.
\end{abstract}

Kata kunci :minyak jelantah, pengurangan FFA, pengurangan warna

\begin{abstract}
Jelantah is a cooking oil that has been used in a few time. It is not only have an unattractive colour and rancid, but also can make a risk to the health. Jelantah can be recovered by adsorbing the impurities and reduce color using the adsorbents. This study aimed to reduce levels of FFA and color of jelantah using coconut fiber and straw adsorbents with variation 50,70 and 100 mesh, variations in pressure at 1 atm and below, and the time variation of adsorption every 10 minutes during the first half hours. In this study, the best adsorbent to reduce free fatty acid (FFA) is coconut fiber with a pressure below 1 atm where FFA value before adsorbed is $0.006823 \mathrm{~N}$ and after being adsorbed $0.0002924 \mathrm{~N}$, whereas for the reduction of oil color, the best adsorbent is straw with 100 mesh size because it reduces the color of 5.5 red and 24 yellow to 3.3 red and 21 yellow.
\end{abstract}

Keywords : reused cooking oil, FFA reduced, color reduced

\section{Pendahuluan}

Minyak goreng merupakan salah satu kebutuhan pokok manusia sebagai alat pengolah bahan-bahan makanan yang biasanya digunakan untuk menggoreng. Minyak goreng nabati biasa diproduksi dari kelapa sawit, kelapa, atau jagung. Penggunaan minyak nabati lebih dari empat kali sangat membahayakan kesehatan. Hal ini terjadi karena penggunaan minyak goreng yang dipakai secara berulang-ulang, bahkan sampai berwarna coklat tua atau hitam dan barulah dibuang. Hal ini dapat menimbulkan dampak negatif bagi yang mengkonsumsinya, yaitu menyebabkan berbagai gejala keracunan, seperti pusing, mual-mual dan muntah. Maka dari itu penggunaan minyak jelantah secara berulang-ulang sangat berbahaya bagi kesehatan [9]. Proses adsorpsi menggunakan suatu bahan yang dapat mengadsorpsi kotoran pada minyak, bahan ini disebut dengan adsorben. Adsorben bukan hanya memisahkan minyak goreng baru, tetapi juga dapat memisahkan padatan pada minyak goreng bekas. Asam lemak merupakan material penting dalam industri oleokimia untuk memproduksi fatty alkohol, sabun, obat, plastik, pelumas, detergen dan secara luas digunakan dalam industri obat dan makanan. Asam lemak bebas pada tumbuhan diperoleh melalui pemutusan ikatan ester, yang kemudian biasanya dipisahkan dalam proses industri. Penelitian untuk menemukan metode yang tepat untuk memisahkan asam lemak bebas telah dilakukan dan adsorpsi telah terbukti sebagai proses yang baik untuk 
memisahkan asam lemak bebas [2]. Masalah yang akan dibahas pada penelitian ini, adalah mempelajari cara pengurangan FFA dan warna dari minyak jelantah dengan menggunakan serabut kelapa dan jerami padi sebagai adsorben.

\section{Teori}

Minyak goreng bekas (jelantah) adalah minyak goreng yang sudah digunakan beberapa kali pemakaian oleh konsumen. Selain warnanya yang tidak menarik dan berbau tengik, minyak jelantah juga mempunyai potensi besar dalam membahayakan kesehatan tubuh. Minyak jelantah mengandung radikal bebas yang setiap saat siap untuk mengoksidasi organ tubuh secara perlahan. Minyak jelantah kaya akan asam lemak bebas. Terlalu sering mengkonsumsi minyak jelantah dapat meningkatkan potensi kanker didalam tubuh. Menurut para ahli kesehatan, minyak goreng hanya boleh digunakan dua sampai empat kali untuk menggoreng [1].

Ada beberapa cara yang dapat digunakan untuk mengetahui apakah minyak goreng tersebut adalah bekas pakai atau tidak, yaitu dapat dilakukan dengan cara:

1. Biasanya minyak campuran tidak mempunyai kebeningan yang sempurna.

2. Walaupun telah disaring, ada beberapa partikel sisa penggorengan yang tertinggal dalam minyak tersebut.

3. Minyak yang pernah dipakai untuk menggoreng ayam akan tercium bau ayam pada jelantah itu.

4. Minyak mudah berasap walau baru dipakai. Jika pada saat penggorengan minyak itu menimbulkan terbentuknya busa yang terlalu banyak, maka ini merupakan tanda-tanda minyak telah rusak [3]

Proses pemurnian minyak dengan menggunakan bleaching earth juga mempunyai kelemahan, yaitu terutama terhadap kualitas minyak, karena banyak sekali zat-zat yang justru diperlukan, seperti beta karoten dan vitamin-E yang ikut teradsorpsi oleh bleaching earth, serta membutuhkan suhu yang relatif tinggi (100$120{ }^{\circ} \mathrm{C}$ ). Suhu yang tinggi dapat menyebabkan minyak teroksidasi. Namun, hal ini dapat dihindari dengan mengkondisikan alat bleaching dalam kondisi vakum untuk mencegah adanya oksigen atau sebelum dilakukannya proses bleaching, oksigen yang ada dalam alat bleaching dikeluarkan terlebih dahulu dengan gas nitrogen [6].
Adsorben bahan alami, adalah adsorben yang berasal dari bahan-bahan alami, seperti tumbuh-tumbuhan dan kayu. Jenisjenis adsorben ini yang biasanya digunakan dalam pembuatan dan pemisahan minyak, yaitu ampas tebu, kulit kacang tanah, daun nenas dan serbuk gergaji. Adsorben ini dapat digunakan sebagai penjernih pada pemisahan minyak, terutama minyak jelantah, karena menggandung selulosa yang terdapat didalam adsorben yang berasal dari bahan-bahan alami tersebut. Serabut kelapa dan jerami padi mengandung selulosa yang di dalam struktur molekulnya mengandung gugus hidroksil atau gugus $\mathrm{OH}$. Zat warna mengandung gugusgugus yang dapat bereaksi dengan gugus $\mathrm{OH}$ dari selulosa sehingga zat warna tersebut dapat terikat pada serabut kelapa dan jerami padi. Zat warna reaktif dapat mewarnai serat selulosa dalam kondisi tertentu dan membentuk senyawa dengan ikatan kovalen atau ikatan hidrogen dengan selulosa. Bila dibandingkan dengan harga adsorben yang berasal dari zeolit alam, harga adsorben yang berasal dari bahan-bahan alami jauh lebih murah. Hal ini dikarenakan, umumnya adsorben yang berasal dari bahan-bahan alami adalah sisa dari bahan (suatu proses) yang tidak memiliki harga ekonomis dan terkadang tidak bisa digunakan kembali untuk suatu proses.

Sebagai perbandingan untuk hasil yang didapat pada penelitian baik FFA maupun warna dengan standar mutu minyak, maka dapat disajikan data seperti pada tabel 1 berikut ini.

Tabel 1. Standar Mutu SPB (Special Prime Bleach) dan Ordinary [5]

\begin{tabular}{|c|c|c|}
\hline & $\begin{array}{c}\text { Special } \\
\text { Prime } \\
\text { Bleach }\end{array}$ & Ordinary \\
\hline $\begin{array}{c}\text { Asam lemak } \\
\text { bebas, \% FFA }\end{array}$ & $1-2$ & $3-5$ \\
\hline Red & $<2,0$ & $<3$ \\
\hline Yellow & 20 & 35 \\
\hline
\end{tabular}

\section{Metodologi Penelitian}

Adsorben yang digunakan berupa serabut kelapa dan jerami padi yang dikeringkan dengan melakukan penjemuran di panas matahari terbuka sampai kering, kemudian dilanjutkan dengan mengeringkan kembali adsorben dengan menggunakan tray dryer, sehingga adsorben benar-benar kering dan memudahkan proses selanjutnya. Kemudian adsorben dimasukkan kedalam ball 
mill, sehingga memudahkan adsorben untuk diayak. Adsorben yang telah dihaluskan didalam ball mil, kemudian di saring menggunakan ayakan dengan ukuran partikel 50 mesh, 70 mesh dan 100 mesh. Sebanyak 150 gr minyak jelantah dimasukkan kedalam beaker glass, kemudian disaring dengan menggunakan kertas saring agar kotoran hasil penggorengan yang terdapat dalam minyak jelantah dapat terpisah. Sebanyak 100 gr minyak jelantah pada proses di atas dimasukkan ke dalam labu leher tiga. Dipanaskan diatas hot plate pada suhu $80{ }^{\circ} \mathrm{C}$ $90{ }^{\circ} \mathrm{C}$ dengan menggunakan pompa vacuum dengan tekanan di bawah 1 atm. Sebanyak 5 gr serabut kelapa dengan ukuran partikel 50 mesh di masukkan ke dalam labu leher tiga. Setiap 10 menit sampel diambil sebanyak $5 \mathrm{ml}$ selama $1 \frac{1}{1} 2$ jam. Sampel didinginkan hingga mencapai suhu kamar. Sampel disaring menggunakan kertas saring untuk memisahkan minyak jelantah dengan adsorben. Filtratnya diambil dan dihitung nilai FFA dan dianalisa warnanya dengan menggunakan lovibond. Dengan cara yang sama dilakukan terhadap ukuran partikel 70 mesh dan 100 mesh, dengan tekanan 1 atm, dan dengan adsorben jerami padi.

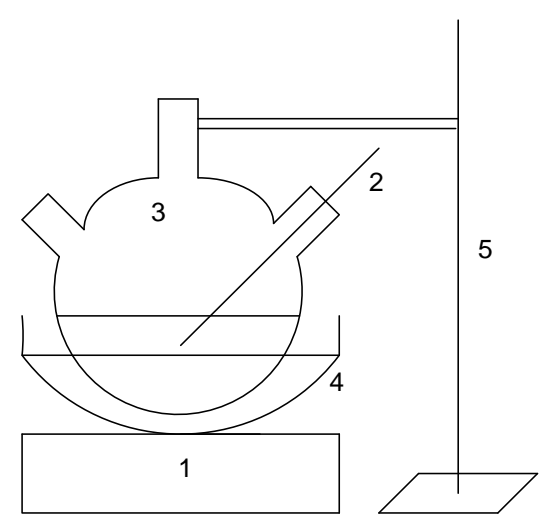

Keterangan :

1.Hot plate

2.Termometer

3.Labu leher tiga

4.Penangas air 5.Statif dan klem

\section{Gambar 1. Rangkaian Alat Percobaan}

Hasil

Pengukuran FFA untuk Adsorben Serabut Kelapa Tekanan 1 atm

Pada run dengan adsorben serabut kelapa pada tekanan $1 \mathrm{~atm}$ sebelum dilakukan proses adsorpsi, nilai FFA minyak jelantah awal adalah sebesar 3,144\%.

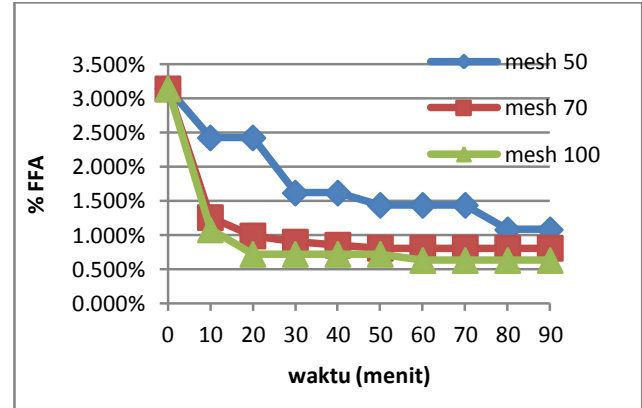

Gambar 2. Hubungan Waktu Adsorpsi terhadap Penurunan Nilai Bilangan Asam (FFA) pada Adsorben Serabut Kelapa Tekanan 1 atm

Dari gambar 2 dapat kita lihat bahwa bilangan asam mengalami penurunan dan kondisi konstan pada interval waktu tertentu. Hal ini dipengaruhi oleh tingkat adsorpsinya.

Pada percobaan dengan ukuran 50 mesh dapat dilihat kondisi konstan kemudian menurun, hal ini dialami karena adsorpsi yang berjalan lambat sehingga didapat grafik konstan kemudian menurun, sedangkan pada percobaan dengan ukuran 70 mesh didapat grafik konstan mulai dari menit 50 sampai akhir proses dan pada ukuran 100 mesh didapat grafik konstan dari menit 60. Bilangan asam minyak jelantah terkecil setelah diadsorpsi didapat dengan menggunakan adsorben ukuran 100 mesh yaitu 0,629\%. Hal ini terjadi dikarenakan oleh bidang kontak yang lebih banyak sehingga diperoleh adsorpsi yang baik.

\section{Pengukuran FFA untuk Adsorben Serabut} Kelapa Tekanan di Bawah 1 atm

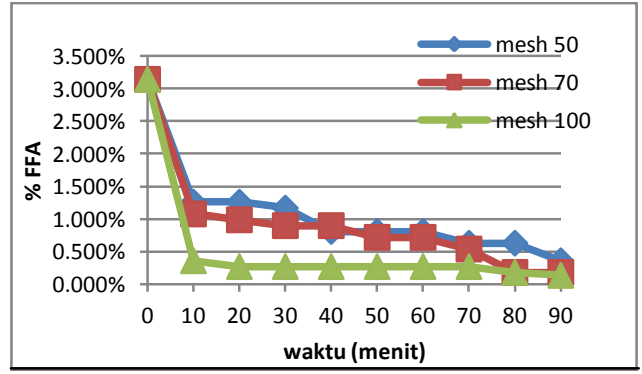

Gambar 3. Hubungan Waktu Adsorpsi terhadap Penurunan Nilai Bilangan Asam (FFA) Pada Adsorben Serabut Kelapa Tekanan di bawah 1 atm

Dari gambar 3 dapat kita lihat bahwa bilangan asam mengalami penurunan dan 
kondisi konstan pada interval waktu tertentu. Hal ini dipengaruhi oleh tingkat adsorpsinya.

Pada percobaan didapat hasil terbaik ialah pada saat menggunakan adsorben ukuran 100 mesh dimana bilangan asamnya adalah $0,135 \%$ dengan kecepatan adsorpsi berjalan lambat dari menit 20 hingga menit 80, hal ini dikarenakan pada saat 10 menit pertama telah banyak FFA yang terserap oleh adsorben serabut kelapa ukuran 100 mesh.

Pengukuran FFA untuk Adsorben Jerami Padi Tekanan 1 atm

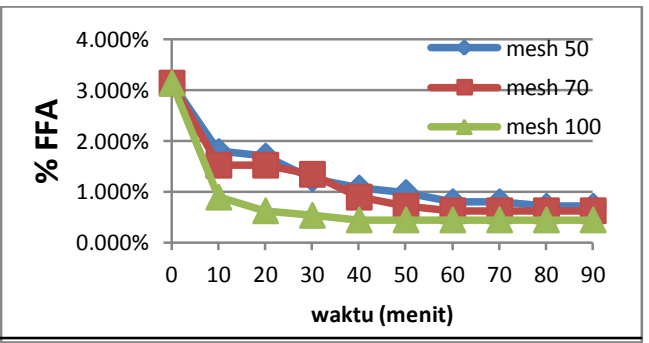

Gambar 4. Hubungan Waktu Adsorpsi terhadap Penurunan Nilai Bilangan Asam (FFA) pada Adsorben Jerami Padi Tekanan 1 atm

Dari gambar 4 di atas dapat dilihat bilangan asam mengalami penurunan seiring dengan lamanya adsorpsi dilakukan, hanya pada percobaan dengan ukuran 100 mesh bilangan asam konstan mulai dari menit 40, hal ini dikarenakan jerami sudah tidak dapat menyerap FFA pada minyak jelantah.

Konsentrasi FFA terkecil didapat pada percobaan dengan ukuran 100 mesh yaitu sebesar $0,449 \%$.

Pengukuran FFA untuk Adsorben Jerami Padi Tekanan di bawah 1 atm

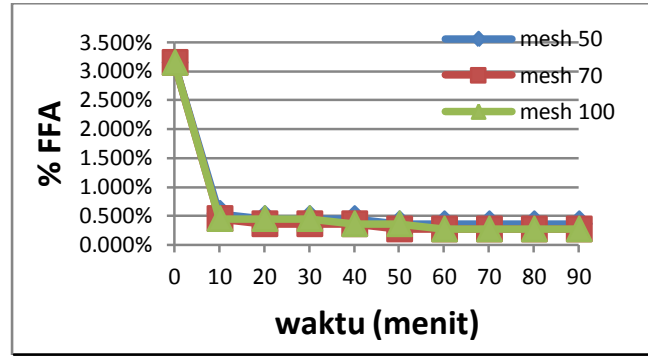

Gambar 5. Hubungan Waktu Adsorpsi terhadap Penurunan Nilai Bilangan Asam (FFA) pada Adsorben Jerami Padi Tekanan di bawah 1 atm

Dari gambar 5 dapat dilihat bahwa $\mathrm{N}$ FFA mengalami penurunan dan konstan pada interval waktu tertentu dan pada semua percobaan terjadi keadaan konstan mulai menit 60, hal ini dikarenakan adsorben sudah mencapai titik maksimum kemampuan untuk mengadsorpsi FFA dari minyak jelantah.

Konsentrasi FFA terkecil di dapat pada percobaan dengan menggunakan ukuran 70 mesh dan 100 mesh pada menit ke 60 yaitu sebesar $0,269 \%$.

\section{Pengurangan Warna pada Minyak}

Penggunaan minyak goreng yang berulang-ulang dengan pemanasan pada suhu tinggi akan menyebabkan terbentuknya berbagai senyawa hasil oksidasi lemak berupa seyawa alkohol, aldehid, keton, hidrokarbon, ester serta bau tengik yang akan mempengaruhi mutu dan gizi bahan pangan yang digoreng. Minyak goreng bekas merupakan limbah yang dapat diolah kembali dengan proses pemucatan menggunakan adsorben [4].

Peningkatan kualitas minyak goreng bekas dapat dilakukan dengan proses adsorpsi. Zat warna dalam minyak akan diserap oleh permukaan adsorben dan juga menyerap suspensi koloid, serta hasil degradasi minyak [8]

Dari analisa sampel awal dengan lovibond diketahui sampel mengandung zat warna 5,5 red dan 24 yellow. Hasil analisa warna setelah dilakukan proses adsorpsi, didapatkan hasil seperti yang ditunjukkan pada grafik.

\section{Hasil Analisa Warna untuk Serabut Kelapa dengan Tekanan di bawah 1 atm}

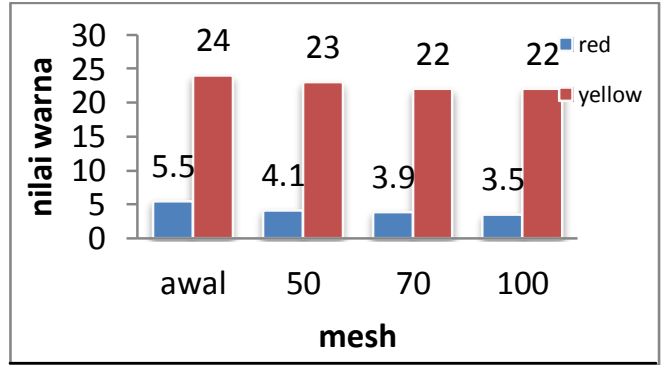

Gambar 6. Perubahan Warna oleh Serabut Kelapa dengan Tekanan di bawah 1 atm

Dari gambar 6 di atas, dapat dilihat perubahan warna oleh serabut kelapa dengan tekanan di bawah $1 \mathrm{~atm}$ diperoleh nilai akhir untuk ukuran 50 mesh adalah 4,1 red 23 yellow. Untuk ukuran 70 mesh adalah 3,9 
red 22 yellow dan untuk ukuran 100 mesh adalah 3,5 red 22 yellow.

\section{Hasil Analisa Warna untuk Serabut Kelapa dengan Tekanan 1 atm}

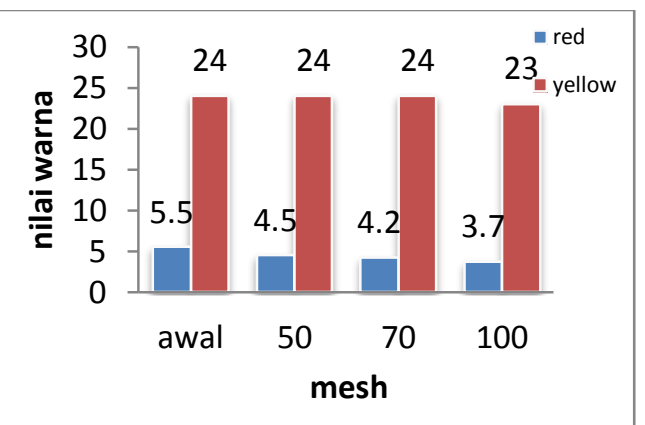

Gambar 7. Perubahan Warna pada Serabut Kelapa dengan Tekanan 1 atm

Dari gambar 7 di atas, dapat dilihat perubahan warna oleh serabut kelapa dengan tekanan 1 atm diperoleh nilai akhir untuk ukuran 50 mesh adalah 4,5 red 24 yellow. Untuk ukuran 70 mesh adalah 4,2 red 24 yellow dan untuk ukuran 100 mesh adalah 3,7 red 23 yellow.

Hasil Analisa Warna untuk Jerami Padi dengan Tekanan di bawah 1 atm

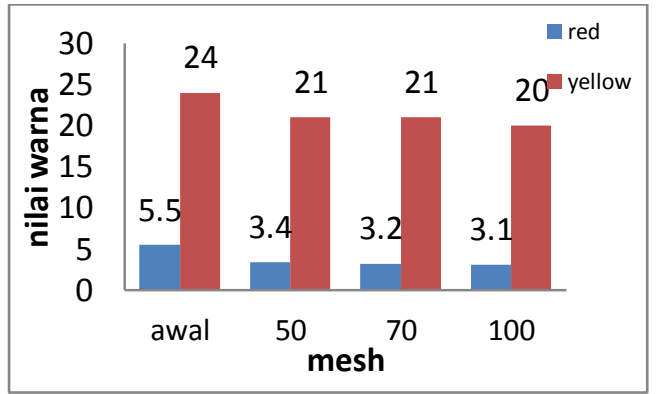

Gambar 8. Perubahan Warna pada Jerami Padi dengan Tekanan di bawah 1 atm

Dari gambar 8, dapat dilihat perubahan warna oleh serabut kelapa dengan tekanan di bawah 1 atm diperoleh nilai akhir untuk ukuran 50 mesh adalah 3,4 red 21 yellow. Untuk ukuran 70 mesh adalah 3,2 red 21 yellow dan untuk ukuran 100 mesh adalah 3,1 red 20 yellow.
Hasil Analisa Warna Untuk Jerami Padi dengan Tekanan 1 atm

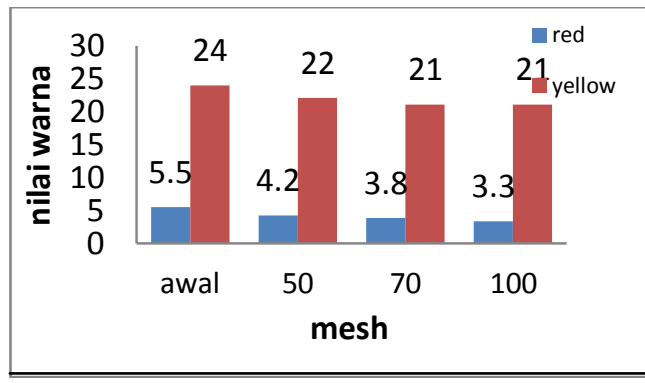

Gambar 9. Perubahan Warna pada Jerami Padi dengan Tekanan $1 \mathrm{~atm}$

Dari gambar 9 di atas, dapat dilihat perubahan warna oleh serabut kelapa dengan tekanan 1 atm diperoleh nilai akhir untuk ukuran 50 mesh adalah 4,2 red 22 yellow. Untuk ukuran 70 mesh adalah 3,8 red 21 yellow dan untuk ukuran 100 mesh adalah 3,3 red 21 yellow.

Dari data yang didapat, baik dengan adsorben serabut kelapa maupun jerami padi bahwa warna pada minyak jelantah semakin berkurang seiring dengan semakin besarnya mesh pada adsorben. Efisiensi adsorpsi merupakan fungsi luas permukaan adsorben, dimana semakin besar luas permukaan adsorben semakin besar pula kapasitas suatu adsorben dalam mengadsorpsi suatu adsorbat. Pengurangan paling efektif didapat pada saat proses adsorpsi menggunakan adsorben jerami padi ukuran 100 mesh, hal ini sesuai dengan teori yang dinyatakan di atas.

Sebagai perbandingan dari kadar warna standar seperti yang diperlihatkan pada tabel 1 , kadar warna standar untuk olein maksimal 3 red, sedangkan pada penelitian ini didapatkan kadar warna red yang paling rendah adalah 3,1 red yaitu dengan menggunakan adsorben jerami padi dengan kondisi tekanan di bawah 1 atm dimana nilai tersebut telah mendekati standar warna.

\section{Kesimpulan}

Dari penelitian yang sudah dilakukan dapat diambil kesimpulan bahwa:

- Penggunaan serabut kelapa dan jerami padi sebagai adsorben dapat menurunkan bilangan asam (FFA).

- Pengurangan warna yang paling efektif didapat pada saat proses adsorpsi menggunakan adsorben jerami padi ukuran 100 mesh yang mengandung zat warna 3,1 red dan 20 yellow. 
- Penurunan FFA maupun pengurangan warna minyak jelantah lebih efektif pada saat keadaan tekanan di bawah $1 \mathrm{~atm}$.

- Bahan-bahan alami yang memiliki kadar selulosa yang tinggi dapat menjadi alternatif untuk digunakan sebagai bahan penyerap (adsorben).

\section{Daftar Pustaka}

[1] Andarwulan, Cara-cara Daur Ulang Minyak Goreng bekas Pakai (Jelantah), ITB, Bandung, 2006.

[2] Chua, Joo Haan, Thesis, The Adsorption of Fatty Acids Using Metal Silica Complexes From Rice Husk Ash, Universiti Sains Malaysia, Kelantan, 2008.

[3] Hariyadi, Priwiyatno, Minyak Goreng Bekas, Waroeng-e Aek-arek Mesin, ITS Surabaya, 2008.

[4] Istighfaro, Nila, Peningkatan Kualitas Minyak Goreng Bekas dengan Metode Adsorpsi Menggunakan BentonitKarbon Aktif Biji Kelor (Moringa oleifera. Lamk) UIN Maulana Malik Ibrahim, Malang, 2010.

[5] Ketaren, S, Pengantar Teknologi Minyak dan Lemak Pangan, Universitas Indonesia, Jakarta, 1986.

[6] Nugraha, Irwan, Bagaimana Mekanisme Bleaching Earth Terhadap Pencegahan Kerusakan Minyak, www.Chem-IsTry.org diakses pada 5 April 2012.

[7] Pasaribu, Nurhida, e-USU repository, Minyak Buah Kelapa Sawit, Universitas Sumatera Utara, Medan, 2004.

[8] Rosita, Alinda Fradiani, Peningkatan Kualitas Minyak Goreng Bekas dari KFC dengan Menggunakan Adsorben Karbon Aktif, Seminar Tugas Akhir Jurusan Teknik Kimia, Universitas Diponegoro, Semarang, 2009.

[9] Suirta, Indah, Journal of Chemistry, Preparasi Biodiesel dari Minyak Jelantah Kelapa Sawit, Universitas Udayana, Bali, 2007. 